\title{
Developments in Animal Husbandry and Food Supply in Roman Germania Inferior
}

\author{
Maaike Groot \\ Amstelveen, The Netherlands
}

The Roman province of Germania Inferior is characterized geographically by the river Rhine-the border of the Empire-and the forts along it. From the north-west to the south-east, there are significant differences in landscape and type of rural habitation. Whether these differences are also noticeable in animal husbandry forms the subject of this article. Are there any differences in species proportions and slaughter ages between the western and eastern parts of the province, and between urban, military, and rural sites? What does this say about farming and food supply? After presenting an overview of the zooarchaeological data from Germania Inferior, I shall discuss in detail one civitas-the civitas Batavorum, with the best known zooarchaeological dataset within the province. What changes in species proportions and cattle size can be detected over time from this civitas? Is there evidence for inter-and intra-site variability and changes in butchery methods? This article's further aim is to demonstrate what kind of questions a synthetic overview of zooarchaeological datasets can address.

Keywords: animal husbandry, Roman period, Germania Inferior, Netherlands, Germany

\section{INTRODUCTION}

Animal husbandry in the Roman period not only produced meat, but also raw materials for industry and transport animals in the form of cattle and horses. It has long been recognized that animal husbandry changed during the Roman period, but only detailed studies of different regions can reveal whether these changes were the same or not throughout the Roman Empire. This paper focuses on the province of Germania Inferior, located on the northern border of the Empire. This region was incorporated into the Empire in the late first century $\mathrm{BC}$, although the province was only formally established sometime between AD 82 and 90 (Willems \& Van Enckevort, 2009: 25, 75). Roman occupation lasted until the late fourth century AD. The province is typified by a strong military presence, with a series of forts situated along the river Rhine. The Rhine formed a convenient transport route for goods. Within the province, there are significant differences in landscape: from the coastal dunes, peat, and river delta in the Central Netherlands to the sandy and loessic soils of the south-eastern Netherlands, to the river plain in the part of the province that is now in modern Germany. Settlements ranged from military camps to large towns. Two main types of rural site can be distinguished: villae, which were agrarian businesses producing food for the urban and military market and which are mainly found in the eastern part of the province; and small clusters of farms, which may also have produced a surplus of food, but on a much 
smaller scale. The latter are dominant in the western part of the province. The presence of imported goods on indigenous sites is a strong indication that local people were active participants in economic networks.

My first aim is to outline broad trends in animal husbandry in Germania Inferior. Were there differences in species proportions and slaughter ages between urban, military, and rural sites, and between the western and eastern parts of the province? If so, what does this say about food supply or dietary preference? By investigating differences between types of site and in animal exploitation, it is possible to establish to what extent animal husbandry and food supply were influenced by environmental factors, farmers' choices, and consumer demand. By examining whether animal exploitation (i.e. slaughter ages) was focused on meat or secondary products, it is possible to discover the relative importance of industry and the degree of specialization in food production.

My second aim is to add more detail and time depth by discussing one civitas, the civitas Batavorum, a region for which an excellent zooarchaeological dataset exists. Are there any changes in species proportions over time, and between urban, military, and rural sites? Is there any interand intra-site variability in species proportions, and if 'yes', what does this say about relative specialization? Do cattle show an increase in size, and if so, when does this take place? Developments in cattle size will be discussed since they reflect changes in the social perception of livestock, changes in economic aims (intensification of meat output or more traction power), know-how of cattle breeding, and economic networks. I will further briefly discuss changes in butchery methods, since this provides information on changes in the perception of animals and technology.
My third aim is to demonstrate what kinds of questions can be addressed in a synthetic overview of zooarchaeological datasets. These questions include: To what extent do environmental factors influence animal husbandry? What is the relationship between site type and meat consumption? Do we find evidence for variation-reflecting different agrarian specialization-between contemporary rural sites in a given cultural region?

\section{Materials and Methods}

The research area is the province of Germania Inferior, but it excludes the civitas Tungrorum as this is covered by Fabienne Pigière's article in this issue (Figure 1). A rough west-east division is used when analysing and discussing the data here. The western part of the province covers the civitates Cananefatium, Batavorum, and Frisiavonum and lies between the towns of Voorburg and Nijmegen. The eastern part of the province covers the civitates Traianensis and Ubii and lies between the towns of Nijmegen and Bonn. A recent article (Groot \& Deschler-Erb, 2015) describes the differences between the datasets from the eastern and western Central Netherlands, so they are not discussed here. Apart from this geographical division, the data are analysed by type of site, distinguishing between military, urban, and rural sites. Military and urban sites provide evidence for consumption of animal products in the first place, but indirectly also for production. In rural sites, evidence for production dominates but is also mixed with evidence for consumption. The available zooarchaeological data are not spread evenly over the province: there is a strong bias towards the western part (mostly the Central Netherlands; see Table 1). There is also a bias towards rural data (Table 1), but this bias is due to the 


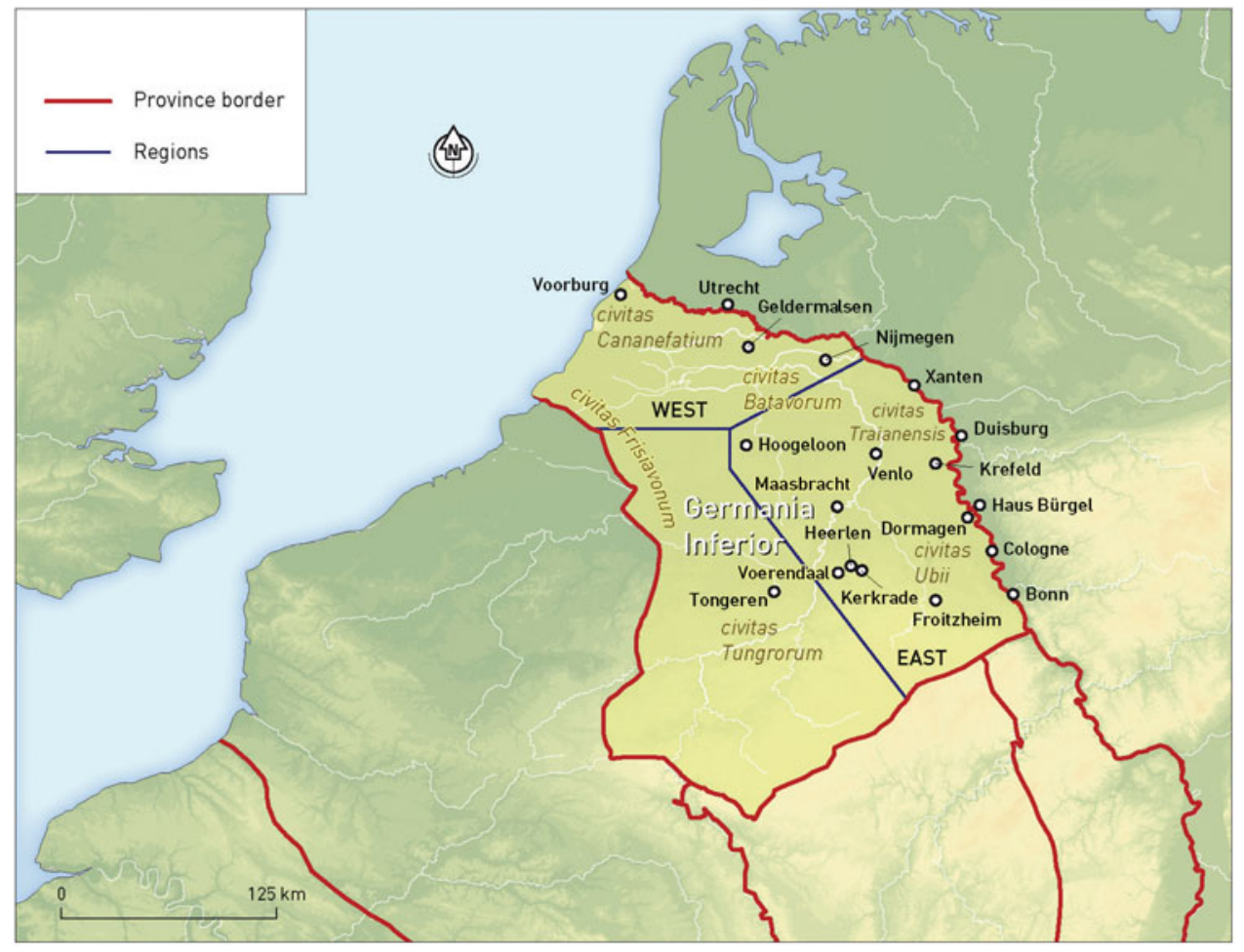

Figure 1. Map of north-western Europe showing the province of Germania Inferior, the civitas Batavorum, and the western and eastern parts of the province as discussed in this article. The southern balf of the province, the civitas Tungrorum, is not considered in this article.

fact that most of the dataset comes from the further bias: small farmsteads dominate in Netherlands, with very few rural sites in western Germania Inferior, while villae Germany having been analysed and pub- form the main type of rural settlement in lished. Within the rural data, there is a eastern Germania Inferior. Because of the

Table 1. Zooarchaeological dataset used in this study.

\begin{tabular}{lcccr}
\hline Area & $\begin{array}{c}\text { n military } \\
\text { assemblages }\end{array}$ & $\begin{array}{c}\text { n urban } \\
\text { assemblages }\end{array}$ & $\begin{array}{c}\text { n rural } \\
\text { assemblages }\end{array}$ & Total \\
\hline Central Netherlands, west & 14 & 12 & 28 & 54 \\
Central Netherlands, east & 11 & 15 & 63 & 89 \\
$\begin{array}{l}\text { Total western Germania } \\
\quad \text { Inferior }\end{array}$ & $\mathbf{2 5}$ & $\mathbf{2 7}$ & $\mathbf{9 1}$ & $\mathbf{1 4 3}$ \\
$\begin{array}{l}\text { South-eastern Netherlands } \\
\text { Germany }\end{array}$ & - & 2 & 5 & 7 \\
Total eastern Germania Inferior & 11 & 11 & 2 & 24 \\
\hline
\end{tabular}

Note: Due to limits of space, I refer to previous publications for a list of sites and references for sites from western Germania Inferior: Groot, 2016; Groot \& Deschler-Erb, 2015, 2016. Sites from eastern Germania Inferior are listed in the appendix. 
small size of the dataset for the eastern part of the province, it is not possible to analyse developments over time there. Such developments will be discussed in more detail for the western part of the province.

To understand the relative importance of different livestock species, percentages were calculated for the main domestic mammals (cattle, sheep or goat, and pig). The percentages were calculated on the basis of the Number of Identified Specimens. Although of lesser importance as a meat provider, horse is included in this study, as it will become clear that this species played an important economic role in the western part of the province. The percentage is calculated out of the total Number of Identified Specimens for the three main domestic animals and horse. Chicken was introduced in the area under study during the Roman period; it therefore reflects the influence of the Roman diet, and the extent to which this was adopted by local people. The percentage of chicken is calculated out of the total Number of Identified Specimens for the three main domestic animals and chicken. To allow for comparison between the two parts of the province and to investigate changes over time, percentages were grouped by region and type of site, and the mean and standard error calculated.

Analysing slaughter ages of cattle, sheep/goat, and pig involved consulting many different publications using different methods of ageing (tooth eruption and wear, epiphyseal fusion or both, and different methods within these basic methods), for which raw data were not always available. The solution used in this and previous articles (Groot \& DeschlerErb, 2015, 2016) is to group assemblages into three broad categories of exploitation: mainly (61 per cent and above) young animals slaughtered, mainly adult animals slaughtered, and finally a roughly equal mixture (between 40 and 60 per cent) of young and adult animals. While this does not provide detailed mortality profiles, it does reveal broad trends in exploitation patterns. For cattle, 'young' means younger than 3-4 years and 'adult' older than 3-4 years; for sheep and goat, 'young' means younger than 2-3 years and 'adult' older than 2-3 years; and for pig, 'young' means younger than 2-3 years and 'adult' older than 2-3 years.

Bone measurements were used to study changes in the size of cattle. Not only were cattle the most important animal in the Roman economy, but it is the only species for which the biometric dataset is large enough for analysis. Nevertheless, changes in cattle size were only investigated for the Central Netherlands, since there are few published data for Germany and the south-eastern Netherlands. The logarithmic scale index (LSI) method, where the $\log$ of a measurement is compared with the $\log$ of a standard (Meadow, 1984, 1999; Uerpmann, 1990), was used to make the most of the available datasets.

The standard consists of the mean for measurements taken for Late Iron Age cattle from Geldermalsen-Hondsgemet, a rural site in the Central Netherlands. Only post-cranial measurements were included. To maximize the dataset, I did not exclude post-cranial measurements that may continue growing post-fusion (Popkin et al., 2012: 1780).

To establish the statistical significance of any differences observed in the dataset for species proportions, the Mann-Whitney U test was used; statistical significance was concluded for $\mathrm{p}$-values lower than 0.05 .

\section{Results}

\section{Germania Inferior: broad trends}

The mean proportions for the main meat providers, i.e. cattle, sheep/goat, and pig, 
show a strong reliance on cattle, which is most pronounced in urban sites (west: 84 per cent; east: 87 per cent; Table 2; Figures 2 and 3). Mean proportions for cattle in military and rural sites are similar within the western area (military: 67 per cent; rural: 68 per cent) and eastern part (military: 46 per cent; rural: 45 per cent), but differ between these areas, with higher proportions of cattle in the western part; these differences are statistically significant (Table 3). Proportions of sheep/goat are highest in rural and lowest in urban sites, and for military and rural sites, higher in the eastern part of the province (although this is only statistically significant for the military sites). Pig shows higher mean proportions in the eastern part of the province (statistically significant for military and rural sites), and within the western and eastern parts, proportions are highest in the military sites and lowest in the urban sites.

The mean proportion of horse is low on military and urban sites in both the western and eastern parts of the research area, as well as in the rural sites in the eastern part (Table 4). For the rural sites in the western part, the mean proportion is much higher, and this difference is statistically significant when compared to all other groups $(p<0.005)$. This high proportion of horse in the western part of the province will be discussed when we look at the civitas Batavorum. Proportions of horse in military and urban sites do not show a statistically significant difference between the western and eastern parts, or when compared to each other.

The proportion of chicken is generally very low, but there are some exceptions (military sites in the Netherlands: Velsen and Nijmegen Castra, and villae in the south-eastern Netherlands: Hoogeloon and Maasbracht 2). The western and eastern parts of the province show no differences in mean proportion of chicken for military and urban sites (Table 4). However, there is a statistically significant difference for rural sites $(p<0.005)$ : the mean for the eastern part is considerably higher than that for the western part.

The exploitation of cattle could be compared for the two parts of the province

Table 2. Mean percentage and standard error per species for the western and eastern parts of Germania Inferior, all phases combined.

\begin{tabular}{|c|c|c|c|c|c|c|}
\hline & \multicolumn{3}{|c|}{ West } & \multicolumn{3}{|c|}{ East } \\
\hline & Cattle & Sheep/goat & Pig & Cattle & Sheep/goat & Pig \\
\hline Military sites & \multicolumn{3}{|c|}{25 assemblages } & \multicolumn{3}{|c|}{11 assemblages } \\
\hline NISP cattle-sheep/goat-pig & \multicolumn{3}{|c|}{39,366} & \multicolumn{3}{|c|}{22,568} \\
\hline Mean percentage & 67.2 & 11.7 & 21.1 & 45.5 & 21.2 & 33.3 \\
\hline Standard error & 3.6 & 1.6 & 3.1 & 5.7 & 3.0 & 3.6 \\
\hline Urban sites & \multicolumn{3}{|c|}{27 assemblages } & \multicolumn{3}{|c|}{13 assemblages } \\
\hline NISP cattle-sheep/goat-pig & \multicolumn{3}{|c|}{39,043} & \multicolumn{3}{|c|}{66,412} \\
\hline Mean percentage & 84.1 & 8.6 & 7.3 & 86.6 & 5.4 & 8.0 \\
\hline Standard error & 1.8 & 1.2 & 1.3 & 3.2 & 1.7 & 1.8 \\
\hline Rural sites & \multicolumn{3}{|c|}{91 assemblages } & \multicolumn{3}{|c|}{7 assemblages } \\
\hline NISP cattle-sheep/goat-pig & \multicolumn{3}{|c|}{44,561} & \multicolumn{3}{|c|}{1724} \\
\hline Mean percentage & 67.9 & 24.2 & 7.9 & 44.7 & 30.5 & 27.0 \\
\hline Standard error & 1.3 & 1.3 & 0.8 & 10.0 & 6.7 & 5.3 \\
\hline
\end{tabular}




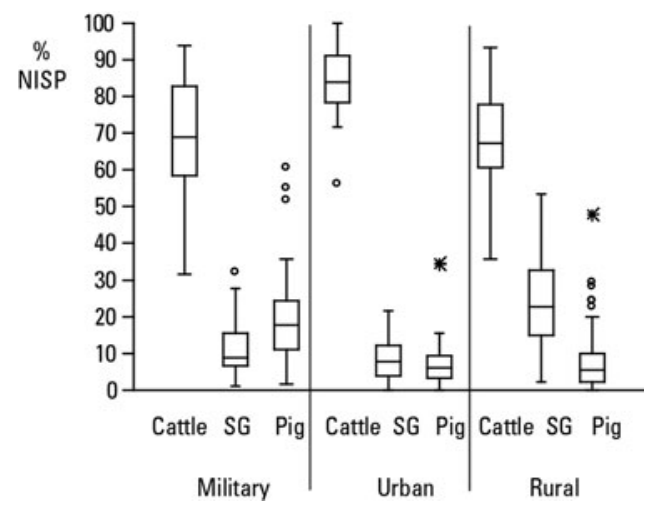

Figure 2. Box plot representing the percentage of cattle, sheep/goat, and pig for military, urban, and rural sites in the western part of Germania Inferior. The two asterisk outliers are the urban Early Roman assemblage from Oppidum Batavorum (modern Nijmegen) and the rural Late Roman assemblage from Medel 6. In the latter case, the small sample size $(n=59)$ could partly explain the abnormally bigh percentage of pig.

and by type of site. In the eastern part of the province, more assemblages show an emphasis on adult cattle (Figure 4). Rural assemblages more often have a preponderance of young cattle than military and urban assemblages. An emphasis on adult cattle is most common in urban sites, and least common in rural sites.

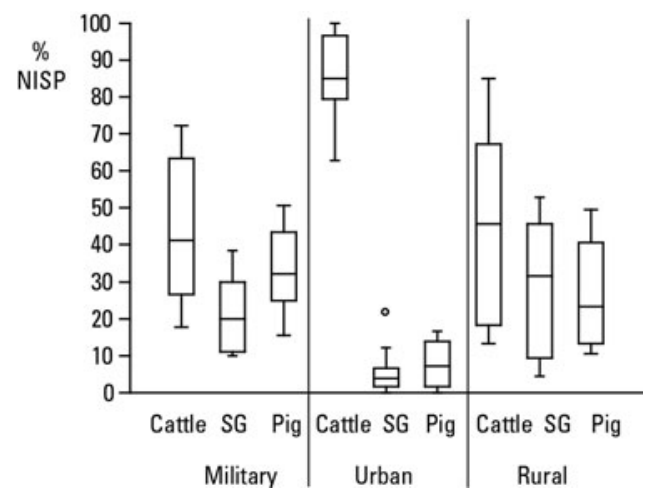

Figure 3. Box plot representing the percentage of cattle, sheep/goat, and pig for military, urban, and rural sites in the eastern part of Germania Inferior.
As for cattle, there is a stronger focus on adult sheep and goats in the eastern part of the province (Figure 5). Exploitation is quite variable in both parts, with 53 per cent (west) and 44 per cent (east) of assemblages concentrating on young sheep/goats and the rest on either adults or a range of ages. Urban sites display the strongest specialization on young animals, although it has to be taken into account that the sample size is small.

It should not come as a surprise that there is a strong emphasis on young animals among pigs in both parts of Germania Inferior and in all site types (Figure 6). Unlike cattle and sheep, pigs cannot be kept for milk, traction, or wool. The exploitation of pigs for meat is most pronounced in the eastern part, and more in urban sites than in military and rural sites.

To summarize, cattle were the main meat provider in Germania Inferior. The reliance on cattle is strongest in urban sites; for military and rural sites, proportions are much higher for the western part of the province. In both western and eastern parts, the proportions of sheep and goat are highest in rural sites and those of pig are highest in military sites (and also in rural sites in the eastern area). Overall, the proportions of sheep or goat and especially pig are higher in the eastern part of the province. The mean proportion of horse is similar in most types of site, except for rural sites in western Germania Inferior, where it is considerably higher than anywhere else. Although the proportion of chicken is highest in rural sites in eastern Germania Inferior, it is still low, with 3 per cent. Slaughter ages of cattle show a stronger emphasis on adult animals in the eastern part of the province; in both parts, a focus on young cattle is found more often in rural sites and least often in urban sites. For sheep and goat, the emphasis on adult animals is stronger in eastern Germania Inferior; for pig, the opposite is the case. 
Table 3. Statistical test results for comparison of species proportions per type of site and region.

\begin{tabular}{|c|c|c|c|c|c|}
\hline & West urban & West rural & East military & East urban & East rural \\
\hline \multicolumn{6}{|c|}{ Cattle } \\
\hline West military & $* * * *$ & $\mathrm{~N}$ & $* *$ & & \\
\hline West urban & & $* * * *$ & & $\mathrm{~N}$ & \\
\hline West rural & & & & & * \\
\hline East military & & & & ***** & $\mathrm{N}$ \\
\hline East urban & & & & & $* * *$ \\
\hline \multicolumn{6}{|c|}{ Sheep } \\
\hline West military & $\mathrm{N}$ & $* * * *$ & $* *$ & & \\
\hline West urban & & $* * *$ & & $\mathrm{~N}$ & \\
\hline West rural & & & & & $\mathrm{N}$ \\
\hline East military & & & & $* * * *$ & $\mathrm{~N}$ \\
\hline East urban & & & & & $* * *$ \\
\hline \multicolumn{6}{|c|}{ Pig } \\
\hline West military & $\mathrm{N}$ & $* * *$ & $*$ & & \\
\hline West urban & & $* * * *$ & & $\mathrm{~N}$ & \\
\hline West rural & & & & & $* * *$ \\
\hline East military & & & & $* * * *$ & $\mathrm{~N}$ \\
\hline East urban & & & & & $* *$ \\
\hline
\end{tabular}

Note: ${ }^{*} p<0.05 ;{ }^{* *} p<0.01 ; * * * 0.005 ; N$ no significant difference (Mann-Whitney $U$ test).

Table 4. Mean percentage and standard error for horse and chicken for the western and eastern parts of Germania Inferior, all phases combined.

\begin{tabular}{|c|c|c|c|c|}
\hline & \multicolumn{2}{|c|}{ West } & \multicolumn{2}{|c|}{ East } \\
\hline & Horse & Chicken & Horse & Chicken \\
\hline Military sites & 25 assemblages & 22 assemblages & \multicolumn{2}{|c|}{6 assemblages } \\
\hline Mean percentage & 3.8 & 3.0 & 5.6 & 1.0 \\
\hline Standard error & 1.0 & 1.4 & 2.9 & 0.3 \\
\hline Urban sites & 26 assemblages & 21 assemblages & \multicolumn{2}{|c|}{13 assemblages } \\
\hline Mean percentage & 3.6 & 0.8 & 2.3 & 0.6 \\
\hline Standard error & 1.0 & 0.2 & 1.0 & 0.2 \\
\hline Rural sites & 91 assemblages & 89 assemblages & \multicolumn{2}{|c|}{7 assemblages } \\
\hline Mean percentage & 15.2 & 0.1 & 2.6 & 3.3 \\
\hline Standard error & 1.0 & 0.0 & 1.0 & 1.0 \\
\hline
\end{tabular}

The civitas Batavorum

We have observed general differences in species proportions and livestock exploitation between military, urban, and rural sites, as well as differences between the western and eastern parts of Germania Inferior. By taking the civitas Batavorum as a case study, we can see whether this smaller region fits the broad patterns 


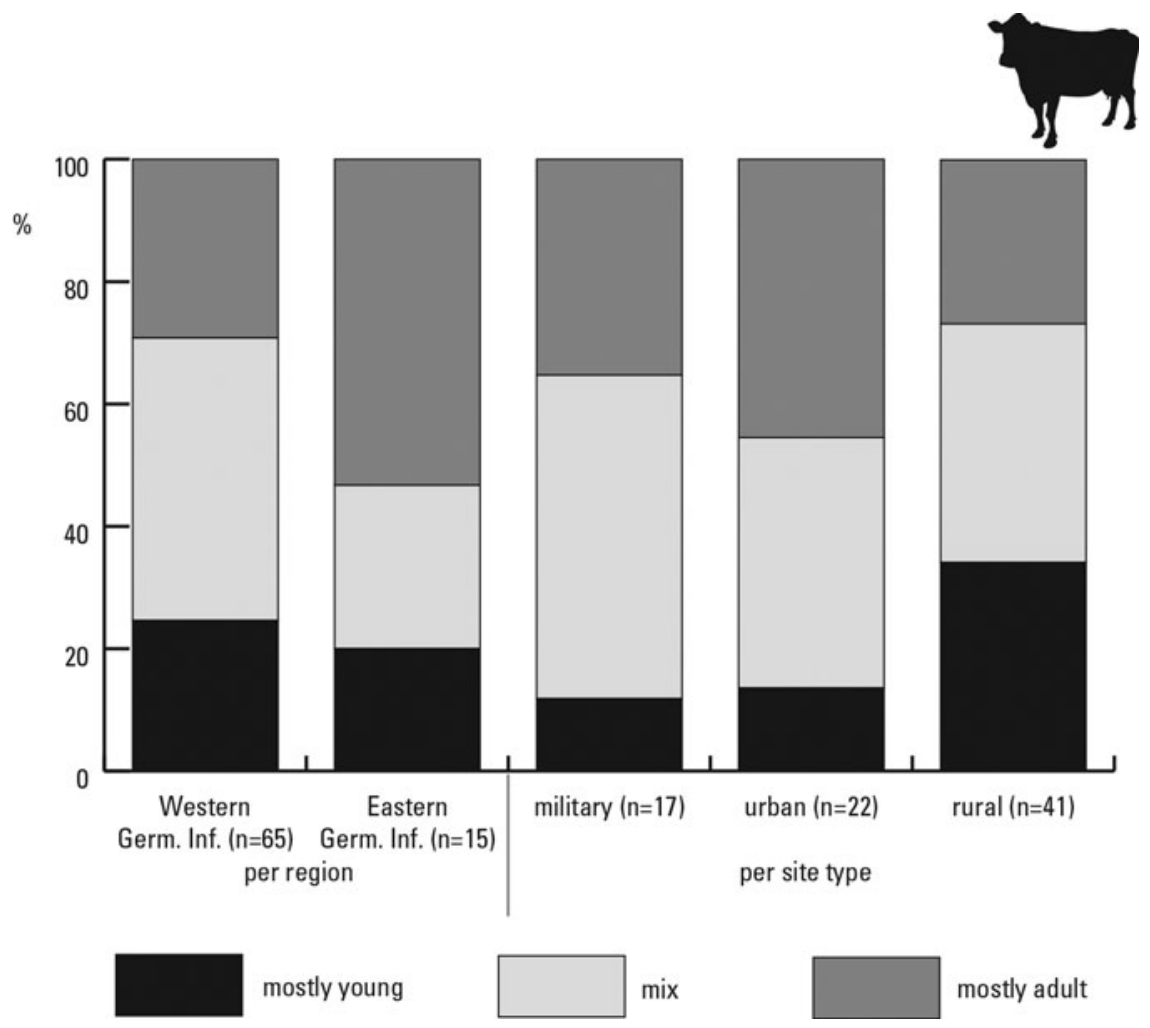

Figure 4. Slaughter ages of cattle by region and type of site. Percentages out of the number of assemblages for which age data were available. Western Germania Inferior: 13 military, 14 urban, and 38 rural assemblages. Eastern Germania Inferior: 4 military, 8 urban, and 3 rural assemblages.

established for the province of Germania Inferior as a whole. The dataset from the civitas Batavorum also allows us to add time depth; this will help us establish whether the patterns observed are constant or change over time.

Figure 7 clearly shows that cattle are the dominant species in all periods and types of site. The proportion of cattle increases during the Middle Roman period (AD 70270); for rural sites, it increases even further in the Late Roman period. On rural sites the proportion of sheep/goat decreases over time, while that of horse increases in the Middle Roman period and that of pig in the Late Roman period. The proportion of pig in military and urban sites decreases in the Middle Roman period. Proportions of horse are high for Middle Roman rural sites and the Late Roman military site of Nijmegen.

When describing broad trends, the variation between individual sites is overlooked. Figure 8 shows species proportions for several assemblages from six rural sites dating to the period $\mathrm{AD} 70-200$. In some cases differences can be explained by a difference in date, but contemporary sites also show variation. The first four assemblages in Figure 8 are contemporary (c. $\mathrm{AD}$ 70-150), as are Tiel-Oude Tielseweg phase 4 (OTW4) and Kesteren-De Woerd phase d (KEWd) (c. AD 110-170). Cattle are the main species in all but one assemblage, and proportions of pig are generally low (less than 10 per cent), while 


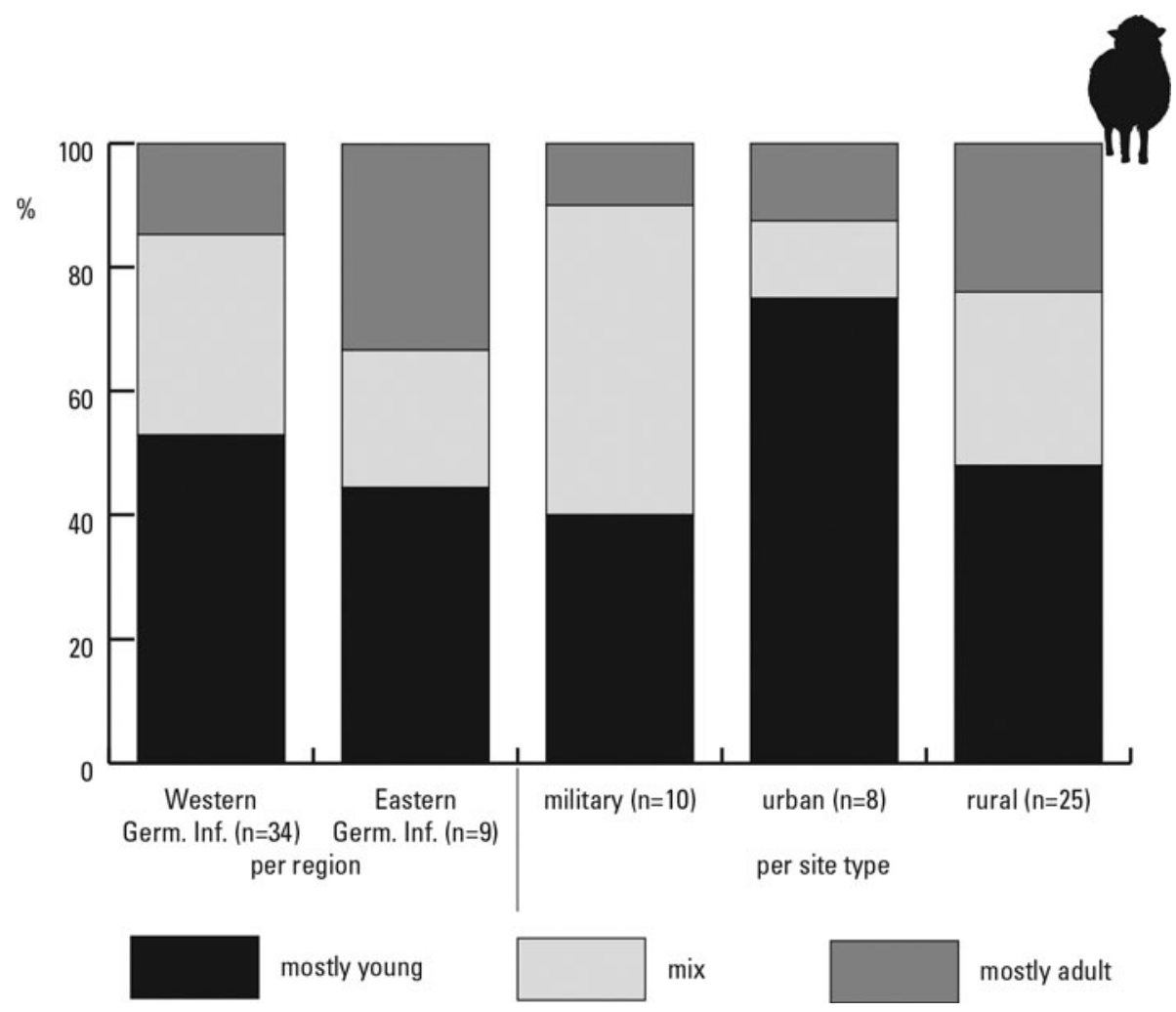

Figure 5. Slaughter ages of sheep/goat by region and type of site. Percentages out of the number of assemblages for which age data were available. Western Germania Inferior: 5 military, 6 urban, and 23 rural assemblages. Eastern Germania Inferior: 5 military, 2 urban, and 2 rural assemblages.

proportions of sheep/goat and horse vary greatly.

Figure 9 illustrates the variation between different military sites. While not all date to the same period, and some differences can be explained by differences in chronology, some contemporary sites also show differences. For instance, the assemblage from the watchtower Utrecht-LR39 has a much higher proportion of sheep/ goat and lower proportion of pig than the assemblage from the castra in Nijmegen (NCAS). Cattle are dominant in all sites, except for two assemblages from the Augustan military camp in Nijmegen (NAK/NAT), where pig is the dominant species. High proportions of pig are found elsewhere on early military sites, and can probably be explained by a self-sufficient food supply of the Roman army in the earliest occupation phase (Thijssen, 1988: 64; Cavallo et al., 2008: 74, 76, 78; Deschler-Erb \& Groot, in prep.).

Even within sites, there is variation in species proportions, which in rural sites is likely to reflect differences in animal husbandry and thus economic differentiation between households. A previous study examined animal bones at the level of individual households in three rural settlements (Groot, 2011, 2012). Although the samples were mostly small, a similar pattern was found in several sites and different phases. All households had high proportions of cattle, but some households also showed a relatively high proportion of 


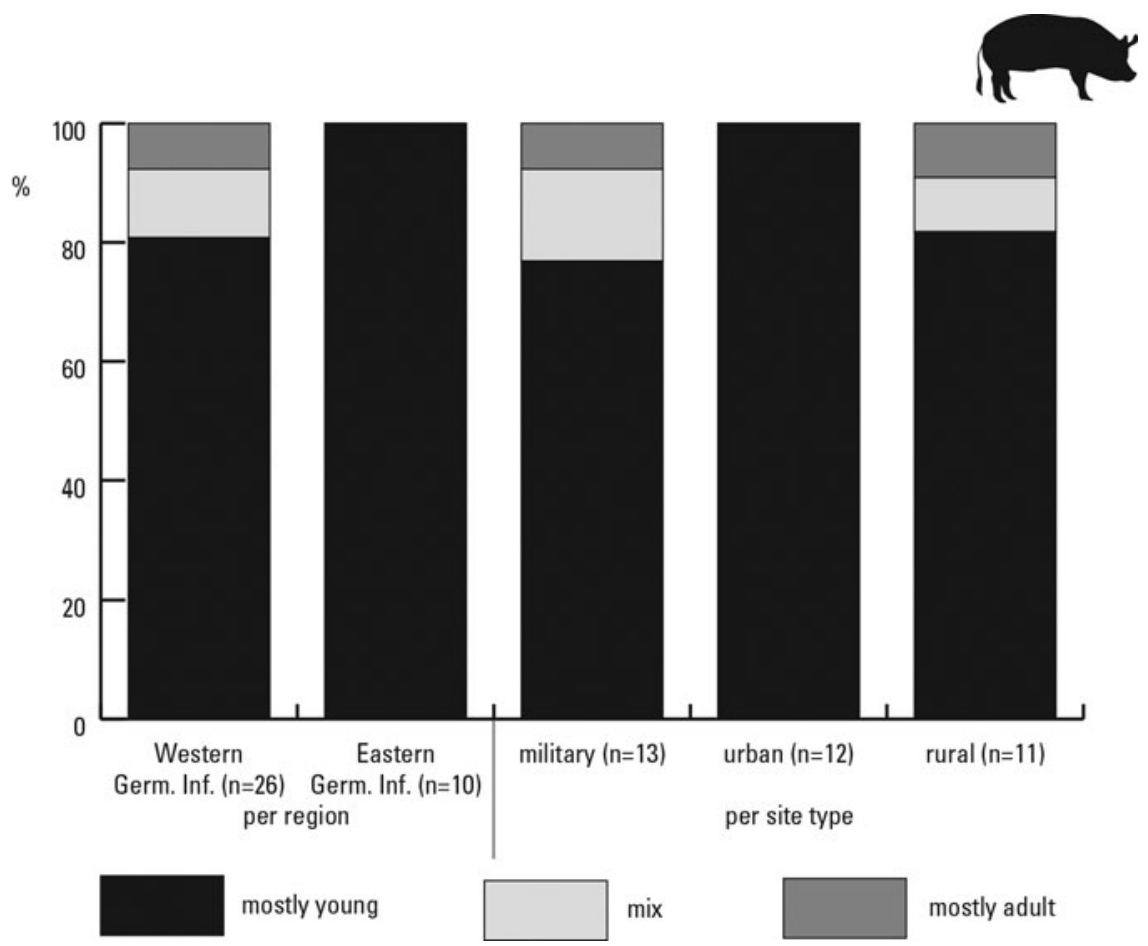

Figure 6. Slaughter ages of pig by region and type of site. Percentages out of the number of assemblages for which age data were available. Western Germania Inferior: 9 military, 8 urban, and 9 rural assemblages. Eastern Germania Inferior: 4 military, 4 urban, and 2 rural assemblages.

sheep, while others showed a relatively high proportion of horse (Figure 10). The households with high proportions of horse have been connected to veterans from the Roman army, since more military gear and horse gear was found in or near these houses; furthermore, some houses had construction elements associated with the Roman army. This has led me to conclude that veterans from the Roman army initiated and maintained the economic specialization in horse breeding found in the civitas Batavorum, using their existing connections in the army to sell their horses.

Two third-century assemblages from Ulpia Noviomagus consist almost entirely of cattle bones and deviate from the other urban assemblages. They reflect the largescale processing of cattle by professional butchers, an activity that is typical for Roman towns. The activities carried out at the two sites differ: one site shows evidence for initial butchery and processing of the head, while the second shows evidence for either further butchery or glue making (Groot, 2016).

As in many other regions of the Roman Empire (e.g. Teichert, 1984; Dobney et al., 1996: 31-33; Lepetz, 1996; Peters, 1998; Schlumbaum et al., 2003; Schibler \& Schlumbaum, 2007; Albarella et al., 2008; Valenzuela et al., 2013; Colominas et al., 2014), cattle increased in size in the civitas Batavorum during the Roman period. Data from the rural sites show that the most significant increase in width and length measurements took place in the Middle Roman period (AD 70-270) (Figures 11 and 12). Bones from urban 


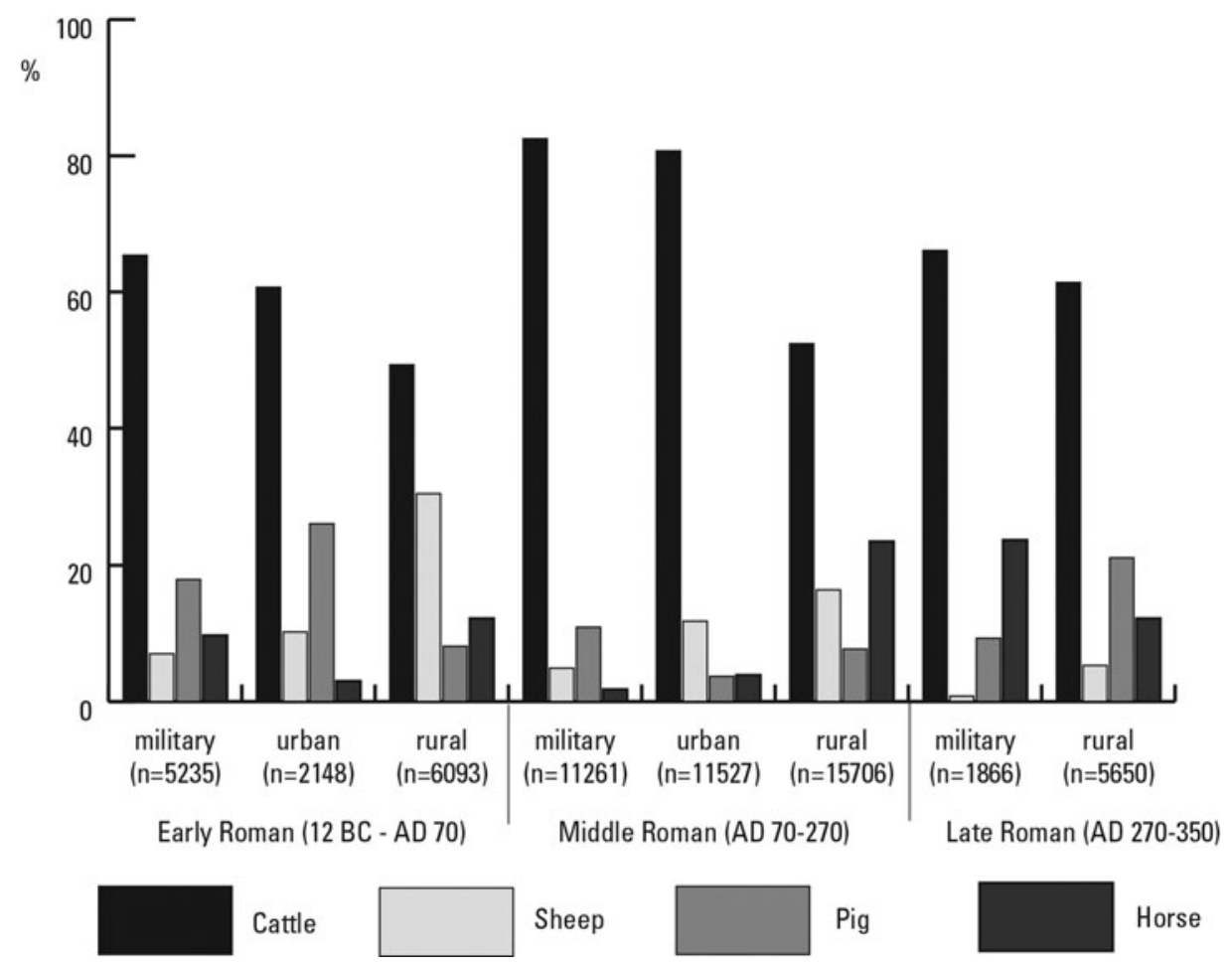

Figure 7. Species proportions of cattle, sheep/goat, pig, and horse by period and type of site in the civitas Batavorum.

and military sites show a similar size increase (Groot, 2016), but the data from these sites are less plentiful.

Food processing, such as butchery, also changed during the Roman period. Evidence for professional Roman butchers in towns has been described for different parts of the north-western Empire (e.g. Maltby, 1989; Oueslati, 2005; Seetah, 2006), but butchery in the countryside has received less attention. In the civitas Batavorum, an increase in chopping marks compared to cut marks has been observed on rural sites (Groot, 2016). There are three explanations for this: first, new technology became available, in the form of cleavers, which have been found on several rural sites; before the Roman period, all butchery was carried out with knives. Second, the change in butchery methods may also have come from the experience of rural people in the army or in towns, where they observed a faster and more efficient way of butchering cattle. Third, the change in butchery practices reflects a changing perception of livestock: dismembering a carcass with knives goes hand in hand with the butcher knowing the individual animal, whereas chopping up a carcass is generally done by people unfamiliar with the animals.

\section{Discussion}

The province of Germania Inferior as a whole shows a strong reliance on cattle for meat, especially when the much larger size of cattle compared to sheep/goat and pig is considered. While this was already 


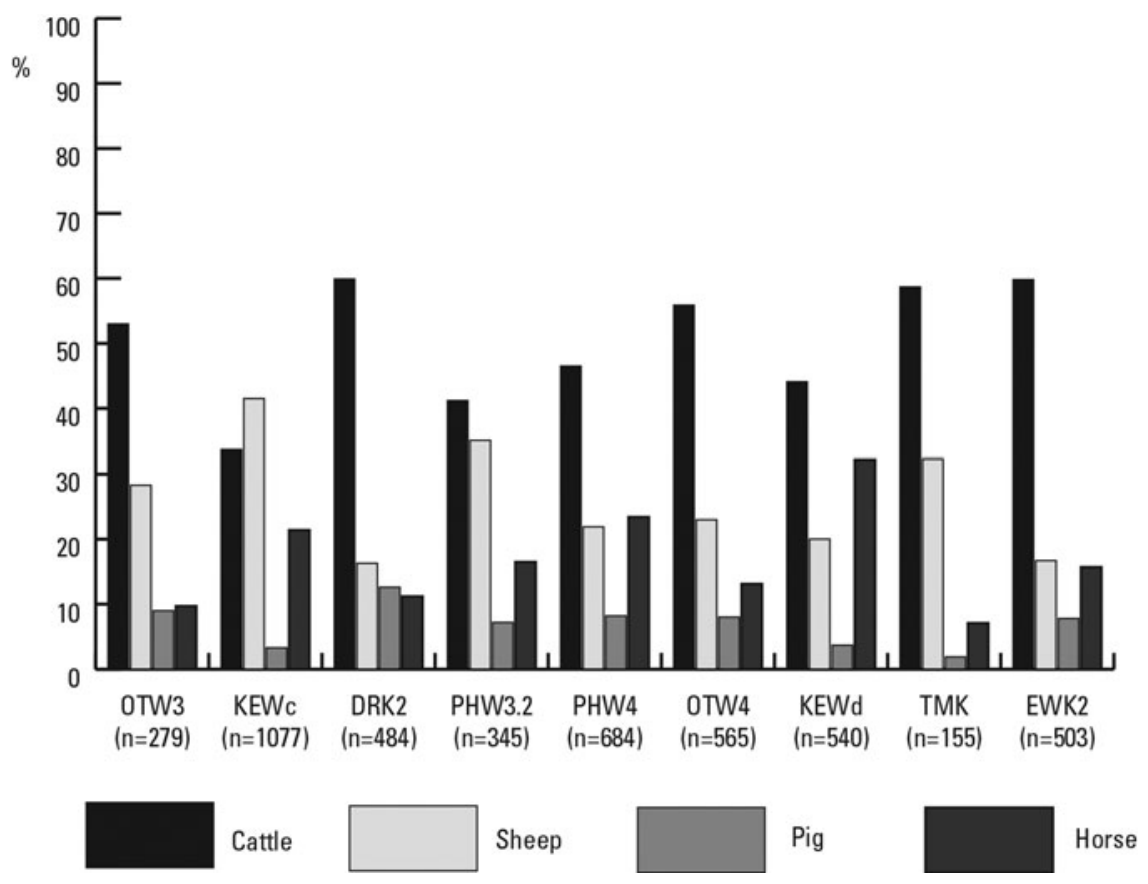

Figure 8. Species proportions of cattle, sheep/goat, pig, and horse for assemblages from six rural sites in the civitas Batavorum, dating to AD 70-200. Site codes: OTW3: Tiel-Oude Tielseweg phase 3 (Groot, 2008); KEWc: Kesteren-De Woerd phase c (Zeiler, 2001); DRK2: Druten-Klepperhei phase 2 (Lauwerier, 1988); PHW3.2: Tiel-Passewaaijse Hogeweg phase 3.2 (Groot, 2008); PHW4: TielPassewaaijse Hogeweg phase 4; OTW4: Tiel-Oude Tielseweg phase 4; KEWd: Kesteren-De Woerd phase d; TMK: Tiel-Medel Krommewei (Van Dijk, 2008); EWK2: Ewijk-Keizershoeve phase 2 (Van Dijk, 2012a).

noted by King (1999) in his review of the Roman Empire, he looked at a much larger area (Germania Inferior, Germania Superior, Raetia, and Noricum). The dominance of cattle is most pronounced on urban sites. Species proportions for urban sites show little difference between the western and eastern parts of the province, while military and rural sites show marked differences between the two regions. The military sites show a much stronger reliance on cattle in western Germania Inferior, with fewer sheep/goat and pig. The rural sites also show much higher proportions of cattle in the western part of the province, while the rural sites in eastern Germania Inferior have higher proportions of pig. These differences in species proportions can be explained in various ways. First, environmental factors may have played a role: the river delta and coastal zone of western Germania Inferior is more suitable for keeping cattle than for keeping pigs. Second, animal husbandry in this region traditionally relied strongly on cattle, with this species playing an important economic and cultural role (Roymans, 1999; Van Dijk \& Groot, 2013). Third, rural settlement in the eastern part of the province consisted of villae, and may have been better able to cater for urban and military customers than the small-scale farmsteads of western Germania Inferior. Finally, the higher proportions of pig in the eastern part of the province may reflect a more 'Roman' taste. This last 


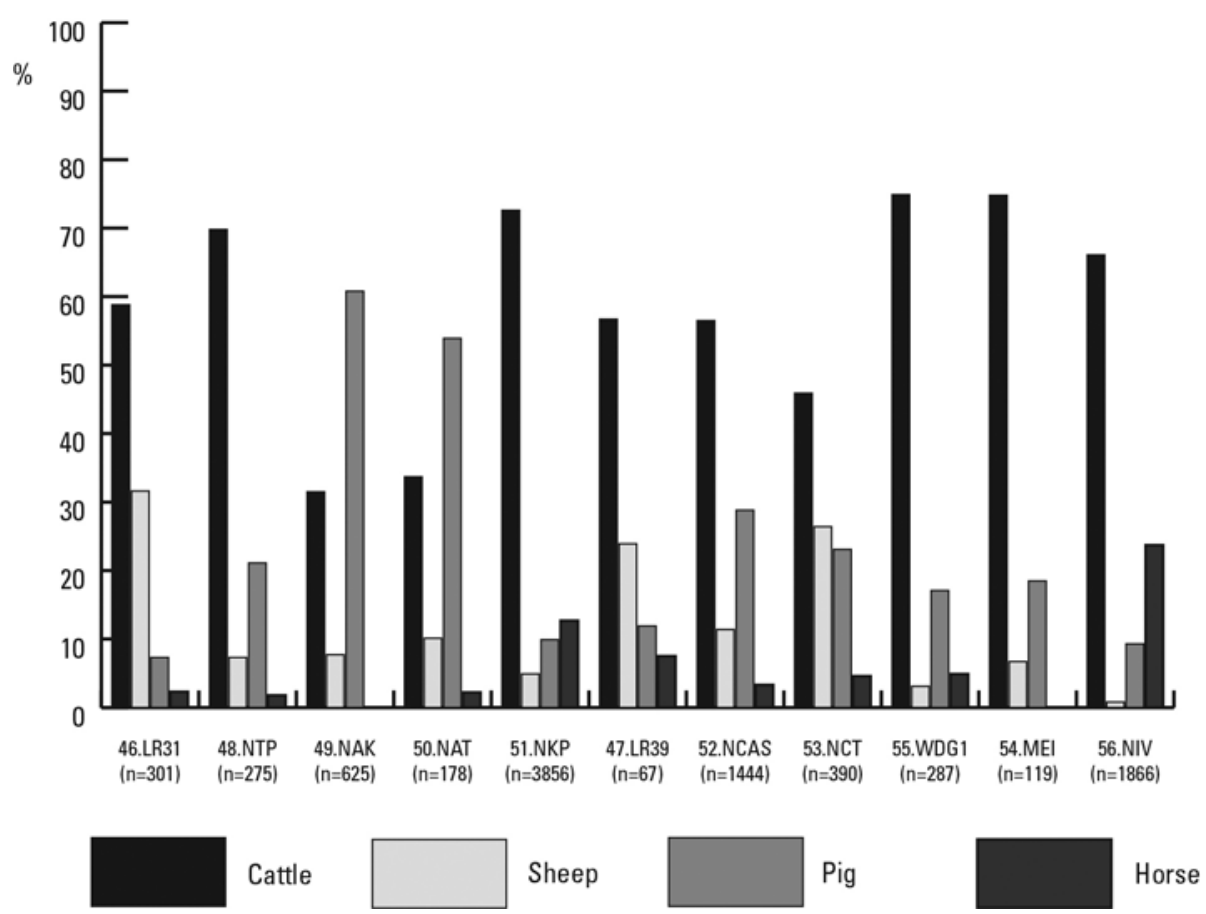

Figure 9. Species proportions on military sites in the civitas Batavorum (after Groot, 2016: fig. 6.1). Site codes: LR31: Utrecht-Leidsche Rijn 31 (Esser et al., 2007); NTP: Nijmegen-Trajanusplein (Lauwerier, 1988); NAK: Nijmegen Augustan camp (Koopmans, 1996); NAT: Nijmegen Augustan camp (Thijssen, 1988); NKP: Nijmegen-Kops Plateau (Whittaker, 2002); LR39: Utrecht-Leidsche Rijn 39 (Van Dijk, 2010); NCAS: Nijmegen Castra (Lauwerier, 1988); NCT: Nijmegen Castra (Thijssen, 1988); WDG1: Wijk bij Duurstede-De Geer 1 (Bekkema et al., 2011); MEI: Meinerswijk (Lauwerier, 1988); NIV: Nijmegen-Valkhof (Lauwerier, 1988).

explanation also applies to the greater proportion of chicken found in rural sites in the eastern part of the province; it is likely that a more 'Roman' diet was consumed in the villae.

The general trend in the exploitation of cattle, sheep/goats, and pigs in the province of Germania Inferior is that the focus on meat is strongest for pigs and the focus on secondary products is strongest for cattle; sheep/goats fall in the middle. This reflects the importance of cattle in industry (e.g. leather, horn) and as a source of labour. The eastern part of the province shows a stronger focus on secondary products from cattle and sheep/goat as well as a stronger emphasis on pig meat. This suggests that a more developed or specialized animal husbandry was present and that industry using animal raw materials was of greater importance. The role of cattle as transport and traction animals may also have played a greater part in this part of the province.

In the civitas Batavorum, proportions of cattle increase over time, while that of sheep/goat decreases. Wool production may have declined over time as transport networks and the importation of wool from other regions were being established. The proportion of horses increases in the Middle Roman period. Proportions of sheep/goat, and horse especially, show significant variation between and also within rural sites. This variation can be explained 


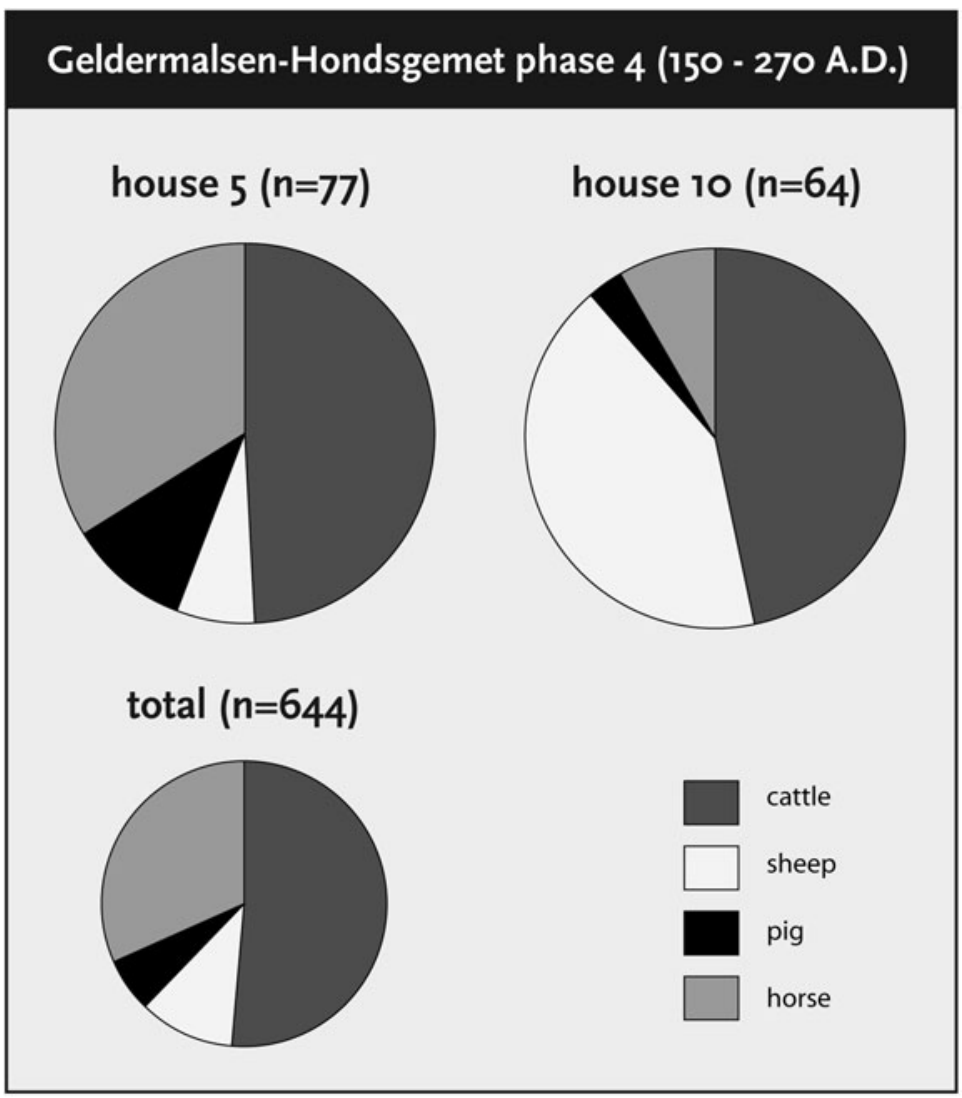

Figure 10. Species composition for house 5 and house 10 (phase 4) at Geldermalsen-Hondsgemet. Illustration by B. Brouwenstijn (Archeologisch Centrum Vrije Universiteit Amsterdam, ACVU) (Groot, 2011: fig. 9).

by different relative specializations in certain animals or animal products. A specialization in horse breeding is typical for this region and probably related to the presence of military veterans. It is likely that a surplus of horses was sold to the Roman army. The Roman preference for pork is visible in the Early Roman period in urban and on military sites, but not in the Middle Roman period. It seems that consumers had to make do with what the local farmers were producing, and that was beef.

The main increase in cattle size takes place in the Middle Roman period. Larger cattle are desirable for two reasons. First, they could draw heavier ploughs or plough heavier soils. Arable farming seems to intensify in this period, and large cattle would have supported this (Groot, 2016). Second, larger cattle produce more meat per animal, so larger cattle can also indicate intensification of meat production. The size increase could have been achieved by crossing larger, imported cattle with the smaller, local type. Selecting larger specimens for breeding would quickly result in a population of larger animals.

Evidence for large-scale butchery and processing of cattle carcasses is found in the town of Nijmegen. Butchery practices in the countryside change during the Roman period, reflecting a change in technology and perhaps also the experience of farmers in the town or in the army. 


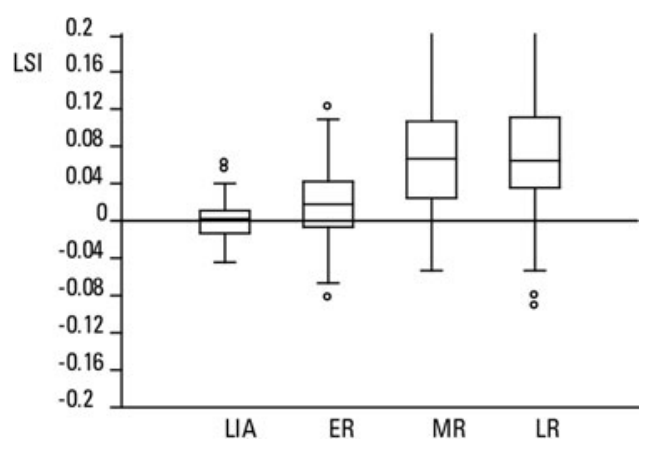

Figure 11. LSI (logarithmic scale index) for width measurements of cattle from rural sites in the civitas Batavorum by period. LIA: Late Iron Age, $n=63$; ER: Early Roman period, $n=98$; MR: Middle Roman period, $n=215$; LR: Late Roman period, $n=152$ (after Groot, 2016: fig. 5.49).

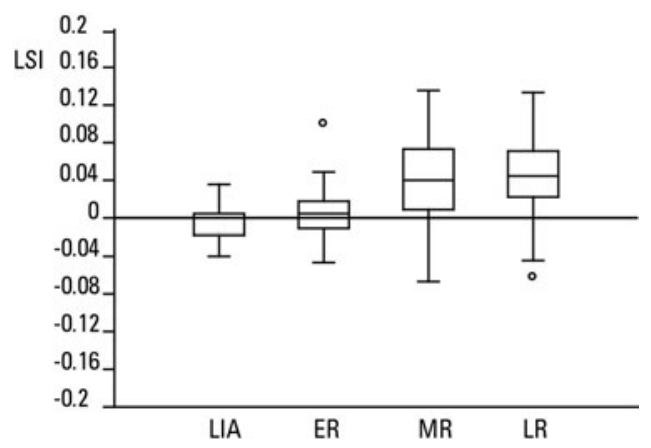

Figure 12. LSI (logarithmic scale index) for length measurements of cattle from rural sites in the civitas Batavorum by period. LIA: Late Iron Age, $n=37$; ER: Early Roman period, $n=63$; MR: Middle Roman period, $n=140 ;$ LR: Late Roman period, $n=78$ (after Groot, 2016: fig. 5.50).

\section{Conclusion}

Although it is possible to outline some general trends in animal husbandry, there is not one single type of animal husbandry that typifies Germania Inferior. There is a lot of variety in rural sites, but also in military sites. Urban sites seem to present the most unified picture when it comes to species proportions: cattle dominate most urban assemblages. Factors that may have determined species proportions include the possibilities or limitations of the local environment for animal husbandry, the degree of adaptation of farmers to market demand, and cultural factors such as dietary preference. In the western part of the province, environmental constraints and farmers' choices seem to have determined supply, while in the eastern part consumer demand seems to have had a greater effect. Exploitation of livestock shows differences between the species, with the secondary products of cattle being more important than those of sheep or goat. As elsewhere in the Roman provinces, cattle size increased in Germania Inferior; this is most noticeable in the second/third centuries AD. Finally, the butchery and processing of cattle should not only be studied in Roman towns, but also on rural sites, as there is evidence in the civitas Batavorum that butchery practices in the countryside changed.

\section{AcKnowledgements}

The author is supported by the Gerda Henkel Stiftung with a Marie Curie Fellowship for the project Sustaining the Empire: farming and food supply in two Roman frontier regions (Grant number AZ 21/EU/12), of which this article forms part. 
Appendix. List of sites from eastern Germania Inferior included in this study.

\begin{tabular}{|c|c|c|c|c|c|}
\hline Site & Site type & Location & Date & $\begin{array}{l}\text { n cattle- } \\
\text { SG-pig }\end{array}$ & References \\
\hline Xanten Insula 38 (2 phases) & urban & Germany & $\begin{array}{l}\text { 1st and } 2 \mathrm{nd} / 3 \mathrm{rd} \\
\text { c. } \mathrm{AD}\end{array}$ & $\begin{array}{r}18,086 \\
2087\end{array}$ & Müller, 1989 \\
\hline Xanten & urban & Germany & $\begin{array}{l}\text { 1st-3rd c., mostly } \\
\text { 1st-2nd c. AD }\end{array}$ & 1441 & Waldmann, 1967 \\
\hline Xanten Insula 34 & urban & Germany & late 1 st c. $\mathrm{AD}$ & 14,125 & Nolde, 2008 \\
\hline Xanten Insula 37 & urban & Germany & $\mathrm{AD} 75-100$ & 209 & Berke, $1995 \mathrm{a}$ \\
\hline Xanten Räucherei & urban & Germany & AD $50-100$ & 1942 & Berke, 1995b \\
\hline Xanten Insula 15 & urban & Germany & $\begin{array}{l}\text { second half } 2 \text { nd } \\
\text { c. } \mathrm{AD}\end{array}$ & 769 & Nolde, 2012 \\
\hline Köln-Jahnstrasse (4 phases) & urban & Germany & $\begin{array}{l}\text { AD } 50-75 ; \\
\text { AD } 75-125 ; \\
\text { AD 125-150; } \\
\text { AD 50-225 total }\end{array}$ & $\begin{array}{r}11,735 \\
581 \\
108 \\
13,897\end{array}$ & Berke, 1996 \\
\hline Heerlen-Valkenburgerweg & urban & SE Netherlands & $1 \mathrm{st}-3 \mathrm{rd} \mathrm{c.} \mathrm{AD}$ & 56 & Van Dijk, 2012b \\
\hline Venlo-Maasboulevard & urban & SE Netherlands & $20 \mathrm{BC}-\mathrm{AD} 230$ & 1376 & Esser et al., 2009 \\
\hline Asciburgium/Duisburg & military & Germany & c. $12 \mathrm{BC}-\mathrm{AD} 89$ & 1066 & $\begin{array}{l}\text { Deschler-Erb, } \\
2007\end{array}$ \\
\hline Köln-Alteburg (6 phases) & military & Germany & $\begin{array}{l}\text { before } \mathrm{AD} 37-\mathrm{AD} \\
\quad 117\end{array}$ & 5581 & Mayer, 2014 \\
\hline Froitzheim & military & Germany & $\begin{array}{l}\text { second half } 3 \mathrm{rd} \\
\text { c. }-4 \text { th c. } \mathrm{AD}\end{array}$ & 1345 & Mennerich, 1968 \\
\hline Dormagen & military & Germany & $\mathrm{AD} 70-4$ th c. $\mathrm{AD}$ & 1416 & Mennerich, 1968 \\
\hline Krefeld-Gellep & military & Germany & $\mathrm{AD} 70-4$ th c. $\mathrm{AD}$ & 124 & Mennerich, 1968 \\
\hline Haus Bürgel & military & Germany & $\begin{array}{l}\text { late } 4 \text { th-early } 5 \text { th } \\
\text { c. } \mathrm{AD}\end{array}$ & 14,625 & Stein, 2000 \\
\hline Köln-Müngersdorf & rural & Germany & $\begin{array}{l}\text { second half } 1 \text { st- } \\
\text { 3rd c. AD }\end{array}$ & 227 & Berke, 1991 \\
\hline Aldenhovener Platte & rural & Germany & $\mathrm{AD} 70-270$ & 106 & Berke, 1999 \\
\hline Hoogeloon-Kerkakkers & rural & SE Netherlands & 2nd/3rd c. AD & 304 & $\begin{array}{l}\text { Kooistra \& Groot, } \\
\quad 2015\end{array}$ \\
\hline Maasbracht (2 phases) & rural & SE Netherlands & 2nd and 3rd c. $\mathrm{AD}$ & $\begin{array}{l}653 \\
127\end{array}$ & $\begin{array}{l}\text { Kooistra \& } \\
\quad \text { Laarman, 1996a }\end{array}$ \\
\hline Voerendaal-Ten Hove & rural & SE Netherlands & 2nd-4th c. AD & 238 & $\begin{array}{l}\text { Kooistra \& } \\
\quad \text { Laarman, 1996b }\end{array}$ \\
\hline Kerkrade-Holzkuil & rural & SE Netherlands & 2nd/3rd c. AD & 69 & $\begin{array}{l}\text { Kooistra \& Esser, } \\
2005\end{array}$ \\
\hline
\end{tabular}

\section{REFERENCES}

Albarella, U., Johnstone, C. \& Vickers, K. 2008. The Development of Animal Husbandry from the Late Iron Age to the End of the Roman Period: A Case Study from South-East Britain. Journal of Archaeological Science, 35: 1828-48.

Bekkema, M., Groot, M., van Haasteren, M. \& Scharringhausen, K. 2011. Dierlijk bot uit Wijk bij Duurstede-De Geer: middenRomeinse tot en met Karolingische tijd (Zuidnederlandse Archeologische Notities 262). Amsterdam: Archeologisch Centrum Vrije Universiteit \& Hendrik Brunsting Stichting.

Berke, H. 1991. Tierreste aus den Ausgrabungen in der römischen Villa Köln-Müngersdorf, Gut Vogelsang. Kölner Jahrbuch, 24: 485-94. 
Berke, H. 1995a. Reste einer spezialisierten Schlachterei in der CUT, Insula 37. Xantener Berichte, 5: 301-06.

Berke, H. 1995b. Knochenreste aus einer römischen Räucherei in der Colonia Ulpia Traiana bei Xanten am Niederrhein. Xantener Berichte, 5: 343-69.

Berke, H. 1996. Die Tierknochenfunde aus den Ausgrabungen an der Jahnstrasse in Köln. Kölner Jabrbuch, 29: 579-604.

Berke, H. 1999. Tierknochen der Spätlatènezeit, der römischen Kaiserzeit und der älteren Merowingerzeit. In: K.H. Lenz, ed. Siedlungen der römischen Kaiserzeit auf der Aldenhovener Platte (Rheinische Ausgrabungen 45). Köln \& Bonn: Rheinland-Verlag \& Habelt, pp. 99-104.

Cavallo, C., Kooistra, L.I. \& Dütting, M. 2008. Food Supply to the Roman Army in the Rhine Delta in the First Century AD. In: S. Stallibrass \& R. Thomas, eds. Feeding the Roman Army: The Archaeology of Production and Supply in NW Europe. Oxford: Oxbow, pp. 69-82.

Colominas, L., Schlumbaum, A. \& Sana, M. 2014. The Impact of the Roman Empire on Animal Husbandry Practices: Study of the Changes in Cattle Morphology in the North-East of the Iberian Peninsula through Osteometric and Ancient DNA Analyses. Archaeological and Anthropological Sciences, doi:10.1007/s12520-013-0116-9.

Deschler-Erb, S. 2007. Tiere in Asciburgium (Funde aus Asciburgium 14). Duisburg: Stadt Duisburg.

Deschler-Erb, S. \& Groot, M. in prep. Think Global, Act Local: Regionalism and the Supply of Meat to the Roman Army. In: M. Allen \& M. Blagg-Newsome, eds. People and Animals in the Western Roman Empire: Zooarchaeological Approaches to Provincial Culture and Economy (Journal of Roman Archaeology Supplementary Series). Portsmouth, RI: Journal of Roman Archaeology.

Dobney, K.M., Jaques, S.D. \& Irving, B.G. 1996. Of Butchers and Breeds: Report on Vertebrate Remains from Various Sites in the City of Lincoln (Lincoln Archaeological Studies 5). Lincoln: Lincoln Archaeology.

Esser, E., Beerenhout, B. \& Kuijper, W. 2007. Dierlijk bot, visresten en schelpen. De wacht aan tafel. In: J.S. van der Kamp, ed. Vroege wacht. LR31 Zandweg: archeologisch onderzoek van twee eersteeeuwse houten wachttorens in Leidsche Rijn (Basisrapportage 16). Utrecht: Gemeente Utrecht, DSO Stedenbouw en Monumenten, Sectie Cultuurhstorie, pp. 144-58.

Esser, E., Beerenhout, B. \& Rijkelijkhuizen, M. 2009. Paleoecologie. Archeozoölogisch onderzoek aan dierlijke resten uit de Romeinse tijd. In: H.M. van der Velde, S. Ostkamp, H.A.P. Veldman \& S. Wyns, eds. Venlo aan de Maas. Van vicus tot stad (ADC Monografie 7). Amersfoort: Archeologisch Diensten Centrum, pp. 249-70.

Groot, M. 2008. Animals in Ritual and Economy in a Roman Frontier Community: Excavations in Tiel-Passervaaij (Amsterdam Archaeological Studies 12). Amsterdam: Amsterdam University Press.

Groot, M. 2011. Household Specialisation in Horse Breeding: The Role of Returning Veterans in the Batavian River Area. In: R. Wiegels, G.A. Lehmann \& G. Moosbauer, eds. Fines imperii - imperium sine fine? Römische Okkupations- und Grenzpolitik im früben Prinzipat (Osnabrücker Forschungen zu Altertum und Antike-Rezeption 14). Rahden, Westfalen: Marie Leidorf, pp. 203-18.

Groot, M. 2012. Animal Bones as a Tool for Investigating Social and Economic Change: Horse-breeding Veterans in the civitas Batavorum. In: I. Schrufer-Kolb, ed. More than Just Numbers? The Role of Science in Roman Archaeology (Journal of Roman Archaeology Supplementary Series 91). Portsmouth, RI: Journal of Roman Archaeology, pp. 71-92.

Groot, M. 2016. Livestock for Sale: Animal Husbandry in a Roman Frontier Zone (Amsterdam Archaeological Studies 24). Amsterdam: Amsterdam University Press.

Groot, M. \& Deschler-Erb, S. 2015. Market Strategies in the Roman Provinces: Different Animal Husbandry Systems Explored by a Comparative Regional Approach, Journal of Archaeological Science Reports, 4: 447-60.

Groot, M. \& Deschler-Erb, S. 2016. Carnem et circenses - Consumption of Animals and their Products in Roman Urban and Military Sites in two Regions in the Northwestern Provinces. Environmental Archaeology published 08 January 2016 
[online] [accessed 4 October 2016] http://www.tandfonline.com/doi/full/10. 1179/1749631415Y.0000000027.

King, A. 1999. Diet in the Roman World: A

Regional Inter-site Comparison of the Mammal Bones. Journal of Roman Archaeology, 12: 168-202.

Kooistra, L.I. \& Esser, K. 2005. Archeobotanie en archeozoölogie. In: G. Tichelman, ed. Het villacomplex KerkradeHolzkuil (ADC-rapport 155). Amersfoort: Archeologisch Diensten Centrum, pp. 297-307.

Kooistra, L.I. \& Groot, M. 2015. The Agricultural Basis of the Hoogeloon Villa and the Wider Region. In: N. Roymans, T. Derks \& H. Hiddink, eds. The Roman Villa of Hoogeloon and the Archaeology of the Periphery (Amsterdam Archaeological Studies 22). Amsterdam: Amsterdam University Press, pp. 141-62.

Kooistra, L.I. \& Laarman, F.J. 1996a. The Zoological Remains from the Cellar. In: L.I. Kooistra, ed. Borderland Farming: Possibilities and Limitations of Farming in the Roman Period and the Early Middle Ages between the Rhine and Meuse. Assen: Van Gorcum, pp. 262-69.

Kooistra, L.I. \& Laarman, F.J. 1996b. The Zoological Remains on the Site of the Roman Villa at Voerendaal. In: L.I. Kooistra, ed. Borderland Farming: Possibilities and Limitations of Farming in the Roman Period and the Early Middle Ages between the Rhine and Meuse. Assen: Van Gorcum, pp. 176-81.

Koopmans, L. 1996. Vroeg-Romeins botmateriaal van de Hunerberg te Nijmegen (unpublished dissertation, University of Amsterdam).

Lauwerier, R.C.G.M. 1988. Animals in Roman Times in the Dutch Eastern River Area (Nederlandse Oudheden 12). Amersfoort: Rijksdienst voor het Oudheidkundig Bodemonderzoek.

Lepetz, S., 1996: Lianimal dans la société Gallo-romaine de la France du Nord (Revue archéologique de Picardie. Numéro spécial 12). Amiens. [online] [accessed 5 January 2017] http://www.persee.fr/issue/ pica_1272-6117_1996_hos_12_1.

Maltby, M. 1989. Urban-rural Variations in the Butchering of Cattle in RomanoBritish Hampshire. In: D. Serjeantson \& T. Waldron, eds. Diet and Crafts in
Towns: The Evidence of Animal Remains from the Roman to the Post-medieval Periods (British Archaeological Reports British Series 199). Oxford: British Archaeological Reports, pp. 75-106.

Mayer, N. 2014. Archäozoologische Untersuchungen an den Tierknochen des römischen Flottenlagers Köln-Alteburg, Phasen 1-5. Kölner Jahrbuch, 47: 41-89.

Meadow, R.H. 1984. Animal Domestication in the Middle East: A View from the Eastern Margin. In: J. Clutton-Brock \& C. Grigson, eds. Animals and Archaeology 3: Early Herders and their Flocks (British Archaeological Reports International Series 202). Oxford: British Archaeological Reports, pp. 309-37.

Meadow, R.H. 1999. The Use of Size Index Scaling Techniques for Research on Archaeozoological Collections from the Middle East. In: C. Becker, H. Manhart, J. Peters \& J. Schibler, eds. Historia Animalium ex Ossibus. Festschrift für Angela von den Driesch. Rahden, Westfalen: Marie Leidorf, pp. 285-300.

Mennerich, G. 1968. Römerzeitliche Tierknochen aus drei Fundorten des Niederrheingebiets, München: Institut für Palaeoanatomie, Domestikationsforschung und Geschichte der Tiermedizin.

Müller, E.C. 1989. Tierknochenfunde aus dem Gelände einer Herberge in der Colonia Ulpia Traiana bei Xanten am Niederrhein. I. Nichtwiederkäuer (unpublished $\mathrm{PhD}$ dissertation, LudwigMaximilians Universität München).

Nolde, N. 2008. Archäozoologische Untersuchungen zu den Tierknochen der Strassenschüttung aus Insula 34 der Colonia Ulpia Traiana (Xanten) (unpublished MA dissertation, Universität Köln).

Nolde, N. 2012. Tierknochen. In: J. Krmäer, Die Befunde und Funde von Insula 15 in der Colonia Ulpia Traiana. Xantener Berichte, 24: 57-197.

Oueslati, T. 2005. Les ossements animaux, l'archéozoologie et les professions de l'alimentation dans le Nord de la Gaule romaine: le cas de la boucherie bovine. Revue du Nord - Archéologie de la Picardie et du Nord de la France, 87: 175-83.

Peters, J. 1998. Römische Tierbaltung und Tierzucht. Eine Synthese aus archäozoologischer Untersuchung und schriftlich-bildlicher Überlieferung, Rahden/ 
Westf. (Passauer Universitätsschriften zur Archäologie 5).

Popkin, P.R.W., Baker, P., Worley, F., Payne, S. \& Hammon, A. 2012. The Sheep Project (1): Determining Skeletal Growth, Timing of Epiphyseal Fusion and Morphometric Variation in Unimproved Shetland Sheep of Known Age, Sex, Castration Status and Nutrition. Journal of Archaeological Science, 39: 1775-92.

Roymans, N. 1999. Man, Cattle and the Supernatural in the Northwest European Plain. In: C. Fabech \& J. Ringtved, eds. Settlement and Landscape. Proceedings of a Conference in Arbus, Denmark, May 4-7 1998. Moesgård, Højbjerg: Jutland Archaeological Society, pp. 291-300.

Schibler, J. \& Schlumbaum, A. 2007. Geschichte und wirtschaftliche Bedeutung des Hausrindes (Bos taurus L.) in der Schweiz von der Jungsteinzeit bis ins frühe Mittelalter. Schweizer Archiv für Tierheilkunde, 149 (1): 23-29.

Schlumbaum, A., Stopp, B., Breuer, G., Rehazek, A., Turgay, M., Blatter, R. \& Schibler, J. 2003. Combining Archaeozoology and Molecular Genetics: The Reason Behind the Changes in Cattle Size between 150BC and 700AD in Switzerland. Antiquity, 77. [online] (accessed 5 January 2017] http://www. antiquity.ac.uk/projgall/schlumbaum/.

Seetah, K. 2006. Multidisciplinary Approach to Romano-British Cattle Butchery. In: M. Maltby, ed. Integrating Zooarchaeology. Oxford: Oxbow, pp. 111-18.

Stein, S. 2000. Viehhaltung, Jagd und Fischfang im "Haus Bürgel", einem spätantiken Kastell am Niederrhein, München: Hieronymus.

Teichert, M. 1984. Size Variation in Cattle from Germania Romana and Germania Libera. In: C. Grigson and J. CluttonBrock, eds. Animals in Archaeology: 4. Husbandry in Europe (BAR International Series 227). Oxford: British Archaeological Reports, pp. 93-104.

Thijssen, J.R.A.M. 1988. Romeins botmateriaal uit Nijmegen en Woerden (unpublished dissertation, University of Amsterdam).

Uerpmann, H.-P. 1990. Die Domestikation des Pferdes in Chalcolithikum West- und Mitteleuropas. Madrider Mitteilungen, 31: 109-53.

Valenzuela, A., Alcover, J.A. \& Cau, M.A. 2013. Tracing Changes in Animal
Husbandry in Mallorca (Balearic Islands, Western Mediterranean) from the Iron Age to the Roman period. In: M. Groot, D. Lentjes and J. Zeiler, eds. Barely Surviving or More Than Enough? The Environmental Archaeology of Subsistence, Specialisation and Surplus Food Production. Leiden: Sidestone Press, pp. 201-23.

Van Dijk, J. 2008. Archeozoölogisch onderzoek. In: E. Blom \& G.L. Williams, eds. Archeologisch onderzoek op de locaties Tiel Medel Krommewei en Ooijsche Wetering. Twee archeologische opgravingen (ADCrapport 1010). Amersfoort: Archeologisch Diensten Centrum, pp. 59-65.

Van Dijk, J. 2010. Zoöarcheologisch onderzoek. In: M.C.M. Langeveld, A. LuksenIjtsma \& E.P. Graafstal, eds. Wegens wateroverlast. LR 39 De Balije II: wachttorens, rivierdynamiek en Romeinse infrastructuur in een rivierbocht van de Heldammer Stroom (Basisrapportage Archeologie 11). Utrecht: Cultuurhistorie Gemeente Utrecht, pp. 171-76.

Van Dijk, J. 2012a. Archeozoölogie. In: E. Blom, L.M.B. van der Feijst \& H.A.P. Veldman, eds. Plangebied Keizershoeve I. Archeologisch onderzoek op De Grote Aalst' te Ewijk (ADC-rapport 2000). Amersfoort: Archeologisch Diensten Centrum, pp. 231-50.

Van Dijk, J. 2012b. Bot. In: G. Tichelman \& M. Janssens, eds. Wonen langs de Romeinse weg in Coriovallum. Valkenburgerweg 25A, gemeente Heerlen. Een definitieve opgraving (RAAP rapport 2210). Weesp: RAAP Archeologisch Adviesbureau, pp. 126-32.

Van Dijk, J. \& Groot, M. 2013. The Late Iron Age-Roman Transformation from Subsistence to Surplus Production in Animal Husbandry in the Central and Western Parts of the Netherlands. In: M. Groot, D. Lentjes \& J. Zeiler, eds. Barely Surviving or More than Enough? The Environmental Archaeology of Subsistence, Specialisation and Surplus Food Production. Leiden: Sidestone Press, pp. 175-200.

Waldmann, K. 1967. Die Knochenfunde aus der Colonia Ulpia Traiana einer römischen Stadt bei Xanten am Niederrbein. ArchaeoPhysika 3. Köln: Böhlau.

Whittaker, W.E. 2002. Zooarchaeological Analysis of the Roman Frontier Economy in the Eastern Netherlands (unpublished $\mathrm{PhD}$ dissertation, University of Iowa). 
Willems, W.J.H. \& Van Enckevort, H. eds. 2009. Ulpia Noviomagus. Roman Nijmegen: The Batavian Capital at the Imperial Frontier (Journal of Roman Archaeology Supplementary Series 73). Portsmouth, RI: Journal of Roman Archaeology.

\section{Biographical Note}

Maaike Groot is a zooarchaeologist currently based in Amsterdam. Her research focuses on animal husbandry and food supply in the Late Iron Age and Roman period in northwestern Europe. A particular interest is the impact of the Roman occupation on agrarian communities. Other research interests include the use of animals in settlement
Zeiler, J.T. 2001. Archeozoölogie. In: M.M. Sier \& C.W. Koot, eds. Kesteren-De Woerd. Bewoningssporen uit de IJzertijd en de Romeinse tijd (Rapportage Archeologische Monumentenzorg 82). Amersfoort: Rijksdienst voor het Oudheidkundig Bodemonderzoek, pp. 217-91.

rituals in Iron Age and Roman Netherlands and animal sacrifice in ancient Greece. Maaike recently finished a Marie Curie project at the University of Basel, comparing animal husbandry and food supply in the Roman Netherlands and Switzerland.

Address: Westduinen 75, 1187JG, Amstelveen, the Netherlands. [email: mgroot73@gmail.com]

\section{Evolution de l'élevage et de l'approvisionnement en Germanie inférieure à l'époque romaine}

Le Rhin domine le paysage de la province romaine de Germanie inférieure et forme une frontière bordée d'établissements militaires. Des différences considérables existent entre le nord-ouest et le sud-est de cette province, au niveau du paysage comme aussi de l'habitat rural. L'article que nous présentons examine cette question: l'élevage reflète-t-il aussi cette diversité ? Pouvons-nous détecter des différences dans les proportions d'espèces représentées ou dans l'âge d'abattage entre les zones occidentales et orientales de la province ou entre les sites urbains, militaires ou ruraux? Que pouvons-nous en conclure sur les pratiques agricoles et sur l'approvisionnement? Après avoir brièvement passé en revue les données archéozoologiques concernant la province de Germanie inférieure, nous examinerons une civitas en plus de détail : la civitas Batavorum, qui a l'avantage de posséder le meilleur ensemble de données archéozoologiques de toute la province. Quels changements dans les proportions d'espèces et dans la taille des bovins cette civitas a-t-elle vu au cours des ans? Pouvons-nous documenter des variations entre les sites et au sein des sites? Et comment les pratiques de boucherie ont-elles évolué ? Enfin cet article vise à démontrer le potentiel d'une approche synthétique des données en archéozoologie et le genre de questions qu'elle peut illuminer. Translation by Madeleine Hummler

Mots-clés: élevage, époque romaine, Germanie inférieure, Pays-Bas, Allemagne

\section{Entwicklung der Viehzucht und der Nahrungsmittelversorgung in der römischen Provinz Germania Inferior}

Die römische Provinz Germania Inferior ist vom Rhein geprägt; der Fluss und die Kastelle an seinem Ufer entlang bildeten die Reichsgrenze. Zwischen dem nordwestlichen und südöstlichen Teil der Provinz gab es deutliche Unterschiede in der Landschaft und im Siedlungswesen. Dieser Beitrag widmet sich der Frage, ob solche Unterschiede auch in der Viehzucht nachweisbar sind. Gibt es zum Beispiel Unterschiede in den Größenverbältnissen bestimmter Tierarten oder im Schlachtalter zwischen dem Westen und Osten der Provinz oder zwischen städtischen, militärischen oder ländlichen Anlagen? 
Was bedeutet das für die Landwirtschaft und die Nahrungsmittelversorgung? Einem kurzen Überblick des zooarchäologischen Materials, das in der Provinz Germania Inferior vorhanden ist, folgt eine ausfübrlichere Besprechung einer bestimmten civitas: die civitas Batavorum. Diese Auswertung kann sich auf den bekanntesten zooarchäologischen Datensatz in der ganzen Provinz stützen. Wie änderten sich die Anteile der Tierarten und die Größe der Rinder im Laufe der Zeit in dieser civitas? Kann man verschiedene Tendenzen innerbalb und auch zwischen den Siedlungen beobachten und wie veränderte sich das Schlachtverfahren? Als weiteres Ziel soll dieser Beitrag dazu dienen, auf Fragen, die man durch eine synthetische Bearbeitung des zooarchäologischen Datenmaterials ansprechen kann, aufmerksam zu machen. Translation by Madeleine Hummler

Stichworte: Viehzucht, Römerzeit, Germania Inferior, Niederlande, Deutschland 